\title{
Synthesis of Polysubstituted Benzothiophenes and Sulfur-Containing Polycyclic Aromatic Compounds via Samarium Diiodide Promoted Three-Component Coupling Reactions of Thiophene-2-carboxylate
}

\author{
Shyh-Ming Yang, ${ }^{\dagger}$ J iun-J ie Shie, ${ }^{\dagger} \mathrm{J}$ im-Min Fang,* Sandip Kumar Nandy, Hung-Yu Chang, \\ Syn-Hung Lu, and Gladys Wang \\ Department of Chemistry, National Taiwan University, Taipei 106, Taiwan, Republic of China \\ jmfang@ccms.ntu.edu.tw \\ Received April 1, 2002
}

\begin{abstract}
By the promotion of samarium diiodide, thiophene-2-carboxylate reacted with 2 equiv of ketones at the C-4 and C-5 positions to give diols such as $\mathbf{2}$ and $\mathbf{9}$. Because the intermediary organosamarium species were oxophilic but not too basic, the double hydroxyalkylations with various ketone substrates, including alkyl aryl ketones, acetylthiophenes, cyclohexanone, $\alpha$-tetralone, and $\alpha$-phenylacetophenones, were real ized without complication of side reactions. The diol products underwent an acid-catalyzed dehydration to give dienes such as 3 and 10, which were treated with DDQ to give either polysubstituted thiophenes (e.g., 4 and 11) or benzothiophenes (e.g., 5, 13, and 14) depending on the reaction conditions. Oxidative annulations of 4,5-diarylthiophenes $\mathbf{1 1}$ and 4,5,6,7tetraphenylbenzothiophenes $\mathbf{1 4}$ were carried out by photochemical or chemical methods to give the sulfur-containing polycyclic aromatic compounds, such as phenanthro[9,10-b]thiophene-2carboxylate, piceno[13,14-b]thiophene-2-carboxylate, and tribenzo[fg,ij,rst]pentapheno[15,16-b]thiophene-2-carboxylates. This method is applicable to the preparation of polysubstituted thiophenes, benzothiophenes, and the related compounds possessing liquid crystalline, photochromic, and other functional properties.
\end{abstract}

\section{Introduction}

Benzothiophenes and their related sulfur-containing polycyclic aromatic derivatives are of interest in many aspects. $^{1-3}$ A recent review ${ }^{1 c}$ evokes the aromaticity ${ }^{\text {la }}$ of these sulfur-containing compounds, reminiscent of polycyclic aromatic hydrocarbons (PAHs), ${ }^{1 b}$ according to the theoretical approach and experimental measurements. The polycyclic aromatic compounds provide the planar structure suitable to DN A intercalation. Phenanthro[c]thiophenes with appropriate substituents have been shown to intercalate with calf thymus DNA specifically at the sites of $\mathrm{A}-\mathrm{T}$ sequence. ${ }^{2}$ Thiophenes and their polycyclic aromatic derivatives also exhibit remarkable el ectrochemical, ${ }^{3 a, b}$ optical, ${ }^{3 c}$ physical, ${ }^{3 d}$ and biological ${ }^{3 e, f}$ properties that render their applications in material and pharmaceutical sciences.

† S.-M.Y. and J .-J .S. contributed equally to this work.

(1) (a) Katritzky, A. R.; J ug, K.; Oniciu, D. C. Chem. Rev. 2001, 101, 1421. (b) Watson, M. D.; Fechtenkötter, A.; Müllen, K. Chem. Rev. 2001, 101, 1267. (c) Schleyer, P. von R. Chem. Rev. 2001, 101, 1115. (2) (a) Wilson, W. D.; Wang, Y. H.; Kusuma, S.; Chandrasekaran, S.; Yang, N. C.; Boykin, D. W. J . Am. Chem. Soc. 1985, 107, 4989. (b) Wilson, W. D.; Wang, Y. H.; Kusuma, S.; Chandrasekaran, S.; Boykin, D. W. Biophys. Chem. 1986, 24, 101 .

(3) (a) Roncali, J. Chem. Rev. 1992, 92, 711. (b) Roncali, J . Chem. Rev. 1997, 97, 173. Miller, L. L.; Mann, K. R. Acc. Chem. Res. 1996 29, 417. (c) Larsen, J .; Bechgaard, K. Acta Chem. Scand. 1996, 50, 71 (d) Müller, M.; Mauermann-Dull, H.; Wagner, M.; Enkelmann, V.; Müllen, K. Angew. Chem., Int. Ed. Engl. 1995, 34, 1583. (e) Tsuji, K.; Nakamura, K.; Ogino, T.; Konishi, N.; Tojo, T.; Ochi, T.; Seki, N.; Matsuo, M. Chem. Pharm. Bull. 1998, 46, 279. (f) Becker, F. F.; Mukhopadhyay, C.; Hackfeld, L.; Banik, I.; Banik, B. K. Bioorg. Med. Chem. 2000, 8, 2693.
Benzothiophenes and the sulfur-containing polycyclic aromatic derivatives are generally prepared by two approaches, ${ }^{4}$ either via construction of a thiophene ring onto an aromatic moiety ${ }^{5}$ or via annulation of an aromatic ring onto a thi ophene moiety. ${ }^{6}$ The first approach can be exemplified by the acid-catalyzed cyclization of dimethoxyethyl phenyl sulfide to give benzothiophene. ${ }^{5 a, b}$ Condensation of 9-chlorophrenthrene-10-carboxaldehyde with mercaptoacetic acid affords phenanthro[9,10-b]thiophene. ${ }^{5 c}$ The reaction of cinnamic acid with thionyl chloride gives 3-chlorobenzothiophene-2-carboxyl chloride. ${ }^{5 \mathrm{~d}-\mathrm{f}}$ The zirconocene complexes of benzyne generated from bromobenzenes are trapped by alkynes and sulfur dichloride to furnish the skeleton of benzothiophenes. ${ }^{5 g}$ Alternatively, the Lewis acid promoted Friedel-Crafts cyclization of 4-thienylalkenoic acid derivatives serves as an instance of the second approach for benzothiophene synthesis. ${ }^{6 a, b}$ The oxidative photocydization of hexatriene systems (e.g., 1-phenyl-2-thienylethene and the related

(4) (a) Campaigne, E. In Comprehensive Heterocyclic Chemistry; Katritzky, A. R., Rees, C. W., Eds.; Elsevier: Oxford, 1984; Vol. 4, pp 863-934. (b) Nakayama, J . In Comprehensive Heterocyclic Chemistry II; Katritzky, A. R., Rees, C. W., Scriven, E. F. V., Eds.; Elsevier: Oxford, 1996; Vol. 2, pp 607-677.

(5) (a) Pié, P. A.; Marnett, L.J . J . Heterocycl. Chem. 1988, 25, 1271. (b) I wao, M.; Lee, M. L.; Castle, R. N. J . Heterocyd. Chem. 1980, 17, 1259. (c) Vögtle, F.; Palmer, M.; Fritz, E.; Lehmann, U.; Meurer, K. Mannschreck, A.; Kastner, F.; Irngrtinger, H.; Huber-Patz, U.; Puff, H.; Friedrichs, E. Chem. Ber. 1983, 116, 3112. (d) Wright, W. B., J r.; Brabander, H.J .J . Heterocycl. Chem. 1971, 8, 711. (e) Sidorenko, T. N.; Terent'eva, G. A.; Aksenov, V. S. Chem. Heterocycl. Compd. (Engl . Transl.) 1983, 161. (f) Camoutsis, C.; Castle, R. N.J . Heterocycl. Chem. 1993, 30, 153. (g) Buchwald, S. L.; Fang, Q. J . Org. Chem. 1989, 54, 3. 


\section{SCHEME 1. Sml 2 -Promoted Three-Component Coupling Reaction as the Key Step for the Transformation of Thiophene-2-carboxylates 1a,b into Thieno-p-terphenyl 5a, \\ Tetraphenylbenzothiophene $14 \mathrm{a}$, and Sulfur-Containing Polycyclic Aromatic Compound 15a}

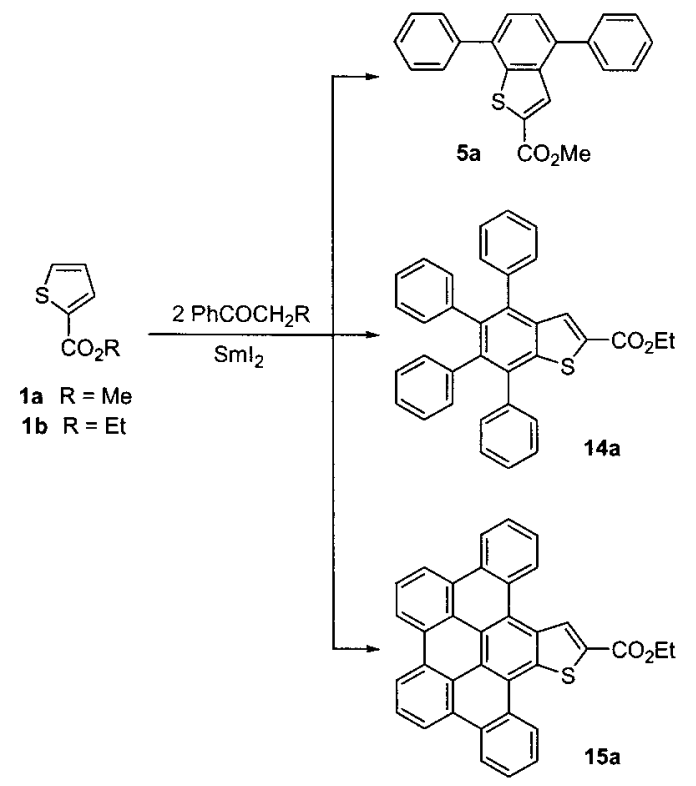

polycyclic analogues) provides a versatile method for aromatic annulation. ${ }^{6-e}-\mathrm{The}$ Michael reaction of 2-(sulfonylmethyl)thiophene-2-carboxaldehyde also affords a series of polysubstituted benzothiophenes. ${ }^{6 f}$ Benzothiophenes have been obtained by the Diels-Alder reactions of 2-vinylthiophenes ${ }^{69}$ and thiophene-2,3-quinodimethane equival ents ${ }^{7}$ generated from thienoi sofurans ${ }^{6 h}$ and thienopyranones. ${ }^{6 i}$ In one case, ${ }^{6 j}$ the copper-mediated coupling of 2,3,4,5-tetraethylzirconacyclopentadiene with 2-iodo3-bromothiophene gives 4,5,6,7-tetraethylbenzo[b]thiophene in $32 \%$ yield. A palladium-catalyzed method for multiple arylation of thiophenes has recently been explored. ${ }^{6 k}$

In addition to the above-mentioned el egant methods, we have devised an $\mathrm{Sml}$--promoted coupling reaction ${ }^{8}$ of thiophene-2-carboxylate in a one-pot procedure to introduce two substituents to the $\mathrm{C}-4$ and $\mathrm{C}-5$ positions. ${ }^{9} \mathrm{Sml}_{2}$ promoted the double el ectrophilic reactions of thiophene2-carboxylate with a variety of ketones, including phenyl methyl ketones, cyclic ketones, and even the enolizable ketones (e.g., $\alpha$-phenylacetophenones). By comparison,

(6) (a) Tominaga, Y.; Teduamulia, M. L.; Castle, R. N.; Lee, M. L. J. Heterocycl. Chem. 1983, 20, 487. (b) Kusuma, S.; Wilson, W. D.; Boykin, D. W. J . Heterocycl. Chem. 1985, 22, 1229. (c) Tinnemans, A. H. A.; Laarhoven, W. H.J . Am. Chem. Soc. 1974, 96, 4611. (d) Buquet, A.; Couture, A.; Lablache-Combier, A.; Pollet, A. Tetrahedron 1981 37, 75. (e) Larsen, J .; Bechgaard, K. Acta Chem. Scand. 1996, 50, 71. (f) Terpstra, J. W.; van Leusen, A. M. J . Org. Chem. 1986, 51, 230. (g) Szmuszkovicz, J .; Modest, E. J. J . Am. Chem. Soc. 1950, 72, 571. (h) Schöning, A.; Debaerdermaeker, T.; Zander, M.; Friedrichsen, W. Chem. Ber. 1989, 122, 1119. (i) J ackson, P. M.; Moody, C. J .; Shah, P. J. Chem. Soc., Perkin Trans. 1 1990, 2909. (j) Takahashi, T.; Hara, R.; Nishimura, Y.; Kotora, M. J . Am. Chem. Soc. 1996, 118, 5154. (k) Okazawa, T.; Satoh, T.; Miura, M.; Nomura, M. J . Am. Chem. Soc. 2002, 124, 5287.

(7) (a) Chou, T.-S. Rev. Heteroatom. Chem. 1993, 8, 65. (b) Peters, O.; Friedrichsen, W. Trends Heterocycl. Chem. 1995, 4, 217. (c) Segura, J. L.; Martin, N. Chem. Rev. 1999, 99, 3199. metalations ${ }^{10 a}$ of thiophene-2-carboxylates and thiophene2-carbamides can only introduce substituents to their C-3 or C-5 positions. Friedel-Crafts reactions of methyl thiophene-2-carboxylate with paraformaldehyde in the presence of $\mathrm{ZnCl}_{2}$ give a mixture of 4-chlromethyl-, 5-chloromethyl-, and 4,5-bis(chloromethyl)thiophene-2carboxylates in $19 \%, 38 \%$, and $15 \%$ yields, respectively. ${ }^{10 b}$ Using the $\mathrm{Sml}_{2}$-promoted coupling reaction appears to be a favorable and direct method for modification of thiophene-2-carboxylate at the C- 4 and C-5 positions. We outlined in Scheme 1 an expedient synthesis of several specifically substituted benzothiophenes (e.g., thieno-pterphenyl 5a and 4,5,6,7-tetraphenylbenzothiophene 14a) as well as the sulfur-containing polycyclic aromatics (e.g., 15a), which are not easily obtained by other methods.

\section{Results and Discussion}

The Sml ${ }_{2}$-promoted three-component coupling reactions of methyl thiophene-2-carboxylate (1a) with 2 equiv of acetophenones afforded diols $\mathbf{2 a}-\mathbf{n}$ in $60-67 \%$ yields (Table 1). The reaction was likely initiated by a hydroxyalkylation at the $\mathrm{C}-5$ position of the thienyl ring (Scheme 2). The samarium dienolate intermediate $\mathbf{A}$ was readily trapped by the second ketone el ectrophi le in a regio- and stereoselective manner. This one-pot procedure thus introduced two substituents to the $\mathrm{C}-4$ and $\mathrm{C}-5$ positions of the dihydrothiophene-2-carboxylate.

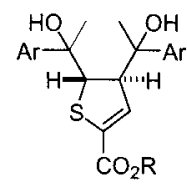

2a-e, $g$<smiles></smiles>

4a-e, g-k

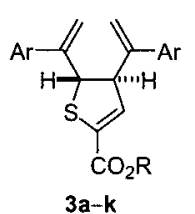

$3 a-k$

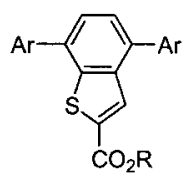

5a-e, g-k

\begin{tabular}{lll}
\hline compound & $\mathrm{R}=$ & $\mathrm{Ar}=$ \\
\hline a series: & $\mathrm{Me}$ & $\mathrm{C}_{6} \mathrm{H}_{5}$ \\
b series: & $\mathrm{Me}$ & $4-\mathrm{ClC}_{6} \mathrm{H}_{4}$ \\
c series: & $\mathrm{Me}$ & $4-\mathrm{MeC}_{6} \mathrm{H}_{4}$ \\
d series: & $\mathrm{Me}$ & $4-\mathrm{MeOC}_{6} \mathrm{H}_{4}$ \\
e series: & $\mathrm{Et}$ & $2-$ naphthyl \\
g series: & $\mathrm{Me}$ & $4-\mathrm{C}_{17} \mathrm{H}_{35} \mathrm{COOC}_{6} \mathrm{H}_{4}$ \\
h series: & $\mathrm{Et}$ & $4-\mathrm{C}_{10} \mathrm{H}_{21} \mathrm{OC}_{6} \mathrm{H}_{4} \mathrm{COOC}_{6} \mathrm{H}_{4}$ \\
i series: & $\mathrm{Et}$ & $4-\mathrm{C}_{12} \mathrm{H}_{25} \mathrm{OC}_{6} \mathrm{H}_{4} \mathrm{COOC}_{6} \mathrm{H}_{4}$ \\
j series: & $\mathrm{Et}$ & $4-\mathrm{C}_{14} \mathrm{H}_{29} \mathrm{OC}_{6} \mathrm{H}_{4} \mathrm{COOC}_{6} \mathrm{H}_{4}$ \\
k series: & $\mathrm{Et}$ & $4-\mathrm{C}_{16} \mathrm{H}_{33} \mathrm{OC}_{6} \mathrm{H}_{4} \mathrm{COOC}_{6} \mathrm{H}_{4}$ \\
\hline
\end{tabular}

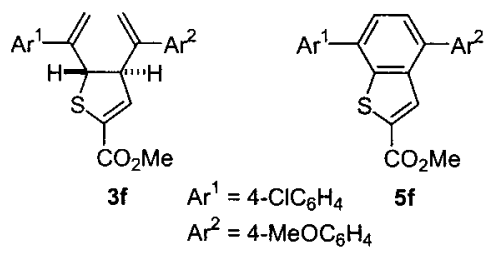

Even though each diol (2a-d) had four asymmetric carbon centers, the diol product usually existed as a mixture of two diastereomers. The diastereomers were separated by silica gel column chromatography. Both 
TABLE 1. Synthesis of 4,7-Diarylbenzothiophenes: (i) Coupling Reactions of Thiophene-2-carboxylate with Aryl Methyl Ketonesa Giving Diols 2, (ii) Dehydration' ${ }^{b}$ Giving Dienes 3, and (iii) DDQ Oxidationc Giving Trienes 4 or Benzothiophenes 5

\begin{tabular}{|c|c|c|c|c|c|}
\hline thiophene & ArCOMe, $\mathrm{Ar}=$ & diol (yield, \%) & diene (yield, \%) & triene (yield, \%) & benzothiophene (yield, \%) \\
\hline la & $\mathrm{C}_{6} \mathrm{H}_{5}$ & $2 \mathbf{a}(61)^{d}$ & $3 \mathbf{a}(90)$ & & $5 \mathbf{a}(90)^{\mathrm{e}}$ \\
\hline la & $4-\mathrm{ClC}_{6} \mathrm{H}_{4}$ & $\mathbf{2 b}(62)^{d}$ & $3 \mathbf{b}(97)$ & $\mathbf{4 b}(89)^{f}$ & $\mathbf{5 b}(91)^{\mathrm{e}}$ \\
\hline $1 \mathbf{a}$ & $4-\mathrm{MeC}_{6} \mathrm{H}_{4}$ & 2c $(60)^{d}$ & $3 c(98)$ & & $5 c(89)^{e}$ \\
\hline la & $4-\mathrm{MeOC}_{6} \mathrm{H}_{4}$ & $2 \mathbf{d}(67)^{d}$ & 3d (95) & & $5 \mathbf{d}(72)^{e}$ \\
\hline $\mathbf{l b}$ & 2-naphthyl & $2 e(50)$ & $3 e(92)$ & $4 \mathbf{e}(82)$ & $5 e(84)^{g}$ \\
\hline $1 \mathbf{a}^{\mathrm{h}}$ & $4-\mathrm{ClC}_{6} \mathrm{H}_{4} / 4-\mathrm{MeOC}_{6} \mathrm{H}_{4}$ & & & & $5 f(43)^{h}$ \\
\hline $1 \mathbf{a}$ & $4-\mathrm{C}_{17} \mathrm{H}_{35} \mathrm{COOC}_{6} \mathrm{H}_{4}$ & & $3 g(48) i$ & & $5 \mathbf{g}(89)^{\mathrm{e}}$ \\
\hline $\mathbf{~} \mathbf{b}$ & 4- $\left(4-\mathrm{C}_{10} \mathrm{H}_{21} \mathrm{OC}_{6} \mathrm{H}_{4} \mathrm{COO}\right) \mathrm{C}_{6} \mathrm{H}_{4}$ & & $3 h(46)^{i}$ & 4h (67) & $5 h(81)^{g}$ \\
\hline $\mathbf{~} \mathbf{b}$ & 4- $\left(4-\mathrm{C}_{12} \mathrm{H}_{25} \mathrm{OC}_{6} \mathrm{H}_{4} \mathrm{COO}\right) \mathrm{C}_{6} \mathrm{H}_{4}$ & & $3 \mathbf{i}(43)^{i}$ & $4 \mathbf{i}(78)$ & $5 i(75)^{g}$ \\
\hline $\mathbf{~} \mathbf{b}$ & 4- $\left(4-\mathrm{C}_{14} \mathrm{H}_{29} \mathrm{OC}_{6} \mathrm{H}_{4} \mathrm{COO}\right) \mathrm{C}_{6} \mathrm{H}_{4}$ & & 3j $(38)^{i}$ & $\mathbf{4 j}(72)$ & $5 \mathbf{j}(71)^{g}$ \\
\hline $\mathbf{~} \mathbf{b}$ & $4-\left(4-\mathrm{C}_{16} \mathrm{H}_{33} \mathrm{OC}_{6} \mathrm{H}_{4} \mathrm{COO}\right) \mathrm{C}_{6} \mathrm{H}_{4}$ & & $3 \mathbf{k}(40)^{i}$ & $4 \mathbf{k}(70)$ & $5 \mathbf{k}(68)^{g}$ \\
\hline $1 \mathbf{a}$ & 2-thienyl & & & & $7 a(38)^{j}$ \\
\hline la & 5-Br-2-thienyl & & & & $\mathbf{7 b}(35)^{j}$ \\
\hline la & 3-Me-2-thienyl & & & & 7c $(36)^{j}$ \\
\hline $1 \mathbf{a}$ & 3-thienyl & & & & $8(42)^{j}$ \\
\hline
\end{tabular}

a Thiophene-2-carboxylate ( $\mathbf{l a}$ or $\mathbf{1 b}$ ) and 2 equiv of aryl methyl ketone in THF/HMPA was treated with $\mathrm{Sml} 2$ at $0-25{ }^{\circ} \mathrm{C}$ for $1-2 \mathrm{~h}$. ${ }^{b}$ The dehydration was achieved by the catalysis of $\mathrm{p}-\mathrm{TsOH}$ in refluxing benzene. ${ }^{\mathrm{c}}$ The reaction with 1.2 equiv of DDQ at $60{ }^{\circ} \mathrm{C}$ gave trienes 4, whereas the reaction with 2.2 equiv of DDQ in refluxing toluene gave benzothiophenes $\mathbf{5}$. ${ }^{d} \mathrm{~A}$ mixture of diastereomers. e The product was obtained by DDQ oxidation of dienes $\mathbf{3}$, and the yield was calculated on the basis of dienes $\mathbf{3}$. ${ }^{\mathrm{f}}$ Accompanied by $5 \%$ of $\mathbf{5 b}$. $\mathrm{g}$ The product was obtained by DDQ oxidation of trienes 4. $^{\mathrm{h}}$ The Sml $\mathrm{S}_{2}$-promoted coupling reaction of la with 1 equiv of 4 -chloroacetylphenone and then with 1 equiv of 4-methoxyacetylphenone. ${ }^{i}$ The overall yield of two steps from $\mathbf{~} \mathbf{l b} .{ }^{j}$ The overall yield of three steps from $\mathbf{l a}$.

diastereomers showed relatively small coupling constants ( $\sim 3 \mathrm{~Hz}$ ) for $\mathrm{H}-4$ and $\mathrm{H}-5$, indicating their trans orientations. The trans configuration could be established by an attack of the second electrophile on the less hindered face of the dienolate intermediate. Although the stereochemistry of diols $\mathbf{2 a}$ - $\mathbf{d}$ was not rigorously determined, the more polar isomers consistently exhibited the $\mathrm{H}-5$ signals at the lower fields than the less polar isomers $\left(\Delta \delta_{H} \approx\right.$ $0.2 \mathrm{ppm}$ ). Under the reaction conditions ( $\mathrm{Sml} / \mathrm{HMPA} /$ $\mathrm{THF}, 25^{\circ} \mathrm{C}, \mathbf{2}-10 \mathrm{~h}$ ), the chlorophenyl groups in $\mathbf{2} \mathbf{b}$ were not reduced. No apparent pinacolic coupling reactions of acetophenones were found to interfere with the $\mathrm{Sml}_{2}$ promoted three-component coupling reactions. By a similar procedure, diol $\mathbf{2 e}$ was prepared in $50 \%$ yield by coupling of ethyl thiophene-2-carboxylate (1b) with 2 equiv of 2-acetylnaphthalene.

On treatment with a catalytic amount of $\mathrm{p}-\mathrm{TsOH}$ in refluxing benzene, diols $\mathbf{2 a}-\mathbf{e}$ underwent dehydrations to yield dienes $\mathbf{3 a}-\mathbf{e}$ with terminal double bonds. Dienes $3 \mathbf{a}-\mathbf{e}$ retained the 4,5-trans configuration. The characteristic C -5 protons appeared at lower fields $\left(\delta_{\mathrm{H}} \approx 6.5\right)$ as doublets with small coupling constants $(\sim 3 \mathrm{~Hz})$. When dienes $\mathbf{3 a}-\mathbf{c}$ were treated with excess amounts of DDQ (2.2 equiv) in refluxing toluene for 7-18 $\mathrm{h}$, the corresponding 4,7-diphenyl benzophenone-2-carboxylates $\mathbf{5 a - c}$ were obtained as the exclusive products in high yields ( $90 \%)$. As benzothiophenes $\mathbf{5 a}-\mathbf{c}$ were formed, the $\mathrm{H}-3$ signals were shifted downfield $\left(\delta_{\mathrm{H}} \approx 8.2\right)$. The yield of 5d $\left(\mathrm{Ar}=\mathrm{p}-\mathrm{MeOC}_{6} \mathrm{H}_{5}\right)$ was somewhat lower (72\%), presumably because the anisole moieties partly decom-

(8) (a) Kagan, H. B.; Namy, J . L.Tetrahedron 1986, 42, 6573. (b) Inanaga, J . J. Synth. Org. Chem. 1989, 47, 200. (c) Soderquist, J. A. Aldrichim. Acta 1991, 24, 15. (d) Brandukova, N. E.; Vygodskii, Y. S. Vinogradova, S. V. Russ. Chem. Rev. 1994, 63, 345. (e) Molander, G. A.; Harris, C. R. Chem. Rev. 1996, 96, 307. (f) Molander, G. A.; Harris, C. R. Tetrahedron 1998, 54, 3321.

(9) (a) Yang, S.-M.; Fang, J .-M. Tetrahedron Lett.1997, 38, 1589. (b) Yang, S.-M.; Nandy, S. K.; Selvakumar, A. R.; Fang, J .-M. Org. Lett. 2000, 2, 3719.

(10) (a) Sniekus, V. Chem. Rev. 1990, 90, 879. (b) Kozmík, V. Paleèek, J. Collect. Czech. Chem. Commun. 1992, 57, 1483. posed on DDQ oxidation. ${ }^{11}$ Under mild reaction conditions, diene $3 \mathbf{b}$ reacted with 1 equiv of DDQ at $60^{\circ} \mathrm{C}$ in benzene to give the primary dehydrogenation product $\mathbf{4 b}$ in $89 \%$ yield. Besides the quantity of DDQ, the reaction temperature was another key factor to manipulate the formation of triene $\mathbf{4 b}$ or benzothiophene $\mathbf{5 b}$. The amount of $\mathbf{5 b}$ increased $(\sim 15 \%)$ at an elevated reaction temperature $\left(>70^{\circ} \mathrm{C}\right)$, even utilizing only 1 equiv of DDQ. The similar phenomena were observed in the DDQ oxidation of $3 e(A r=$ naphthyl). At an elevated temperature, electrocyclization ${ }^{12 a}$ of triene $\mathbf{4 b}$ (or $\mathbf{4 e}$ ) might occur to give the intermediate $\mathbf{B}$. Dehydrogenation of the intermediate could be effected by DDQ to afford benzothiophene $\mathbf{5 b}$ (or 5e). Indeed, the intermediate $\mathbf{B}$ generated from electrocydization of $\mathbf{4 e}$ exhibited the nature of o-thiophenequinodimethane, ${ }^{7 a}$ which was successfully trapped by a dienophile of $\mathrm{N}$-phenylmaleimide to give the $[4+2]$ cycloaddition product 6 (Scheme 2). The cycloaddition was consistent with a concerted mechanism to give adduct 6 in the endo configuration. The NOESY correlation of $\mathrm{H}-4 \mathrm{a} / \mathrm{H}-7 \mathrm{a}(\delta 4.34-4.33, \mathrm{~m})$ with the ethylenebridge protons $(\delta 2.15-2.11, \mathrm{~m})$ supported the stereochemical assignment. Electrocyclization of triene $\mathbf{4 e}$ was also achieved by irradiation with $300-\mathrm{nm}$ light, and the cyclohexadiene intermediate $\mathbf{B}$ could be oxidized to $\mathbf{5 e}$ in the presence of oxygen. ${ }^{12 a}$

A photochromic system between the col orless trienes $\mathbf{4 I - n}$ and their corresponding closed-ring species of yellow col or was devised (Scheme 3). ${ }^{12 b}$ Trienes $\mathbf{4 I}-\mathbf{n}$ were similarly prepared from the $\mathrm{Sml}_{2}$-promoted coupling reactions of $\mathbf{1 b}$ with isobutyronaphthone, isobutyrophenone, and 4-methoxyisobutyrophenone, followed by acidcatalyzed dehydration and DDQ dehydrogenation. Unlike $\mathbf{4 e}$, trienes $\mathbf{4 I}-\mathbf{n}$ carried four methyl substituents to prevent their closed-ring isomers from oxidative aroma-

(11) (a) Lemaire, M.; Guy, A.; Huynh A. H.; Guette, J . P. J anssen Chim. Acta 1987, 5, 3. Cyclohexadiene reagents: a new approach to selectivity control. (b) Fukase, K.; Egusa, K.; Nakai, Y.; Kusumoto, S. Mol. Diversity 1997, 2, 182

(12) (a) Zimmerman, H. E. Acc. Chem. Res. 1971, 4, 272. (b) Shie J.-J .; Yang, S.-M.; Chen, C.-T.; Fang, J .-M. Org. Lett. 2002, 4, 1099. 
SCHEME 2. Reaction Pathways: (i) Sml ${ }_{2}$-Promoted Coupling Reaction, (ii) Hydroxyalkylation of Dienolate Intermediate, (iii) Dehydration, (iv) Dehydrogenation, (v) Electrocylization, (vi) Oxidative Aromatization, and (vii) Trapping of the Proposed o-Thiophenequinodimethane Intermediate B by a Dienophile<smiles>[R6]OC(=O)c1cccs1</smiles><smiles></smiles>

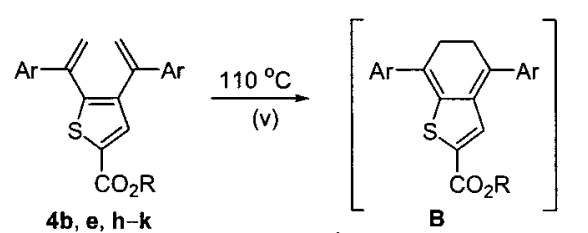
4b, e, h-k<smiles>[R2]OC(=O)c1cc2c(Br)ccc([R])c2s1</smiles>

SCHEME 3. Electrocyclization of Trienes $4 I-n$ upon Irradiation with 300-nm Light in $\mathrm{CH}_{3} \mathrm{CN}$ Solution To Give the Corresponding Closed-Ring Species with Absorption $\lambda_{\operatorname{Max}} \sim 425 \mathbf{n m}^{\mathrm{a}}$<smiles>C/C=C(/Br)c1sc(C(=O)OCC)cc1/C(Br)=C/C(C)C</smiles>

open-ring isomer 4 I $\mathrm{Ar}=2$-naphthyl $4 \mathrm{~m} \mathrm{Ar}=\mathrm{C}_{6} \mathrm{H}_{5}$ 4n $\mathrm{Ar}=4-\mathrm{MeOC}_{6} \mathrm{H}_{4}$

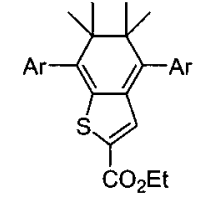

closed-ring isomer a The Interconversion between $4 \mathrm{I}-\mathrm{n}$ and their corresponding closed-ring species constitutes an interesting photochromic system.

tization. The closed-ring isomers $\mathbf{C}-\mathbf{E}$ returned to the open-ring isomers $\mathbf{4 I - n}$ on irradiation with $450-\mathrm{nm}$ light. ${ }^{12 b}$

Diol 2 f bearing two different aryl substituents was prepared by treatment of thiophene-2-carboxylate $\mathbf{1 a}$ consecutively with 1 equiv of 4-chloroacetophenone (stirring for $2 \mathrm{~h}$ at $25^{\circ} \mathrm{C}$ ) and 4-methoxyacetophenone. The acid-catalyzed dehydration of diol $\mathbf{2 f}$ gave diene $\mathbf{3 f}$, which was treated with 2.2 equiv of DDQ in refluxing toluene to afford benzothiophene $\mathbf{5 f}$ in $43 \%$ overall yield. Our present three-step procedure, via the coupling reaction of thiophenecarboxylate with ketones, acid-catalyzed dehydration and DDQ, oxidative cyclization, is thus applicable to the synthesis of various thieno-p-terphenyls ${ }^{13} \mathbf{5} \mathbf{a}-\mathbf{k}$ having the same or different aryl groups. Similar to common terphenyl compounds, the phenyl rings are not coplanar with the benzothiophene ring in these thieno-p-terphenyls. The crystal structure of $\mathbf{5 c}$ showed that two tolyl rings had the dihedral angles of $54^{\circ}$ and $133^{\circ}$, respectively, against the central benzothi ophene ring (see the Supporting I nformation).

By a similar procedure, dienes $\mathbf{3 g}-\mathbf{k}$, trienes $\mathbf{4 g}-\mathbf{k}$, and benzothiophenes $\mathbf{5} \mathbf{g}-\mathbf{k}$ bearing long-chain substituents were prepared. These compounds could be considered to have a pseudo- $C_{2}$ symmetry dissected by the carboxylate group. Among them, dienes $\mathbf{3 h}-\mathbf{j}$ and trienes $\mathbf{4 h}-\mathbf{k}$ possess the liquid-crystalline properties ${ }^{14}$ of smectic-A type. The phase transition temperatures occur in the ranges of $67-47^{\circ} \mathrm{C}$ for $3 \mathbf{h}-\mathbf{j}$ and $72-52{ }^{\circ} \mathrm{C}$ for $\mathbf{4 h}-$ $\mathbf{k}$. Thieno-p-terphenyls $\mathbf{5 h}-\mathbf{k}$ exist as solids with rather high melting points $\left(197-185^{\circ} \mathrm{C}\right)$, even though they are equipped with soft long chains of decoxy, dodecoxy, tetradecoxy, and hexadecoxy groups. By comparison with the thienyl rings in $\mathbf{3 h}-\mathbf{j}$ and $\mathbf{4} \mathbf{h}-\mathbf{k}$, the rigid core of benzothiophene is longer to disfavor the liquid-crystalline property.

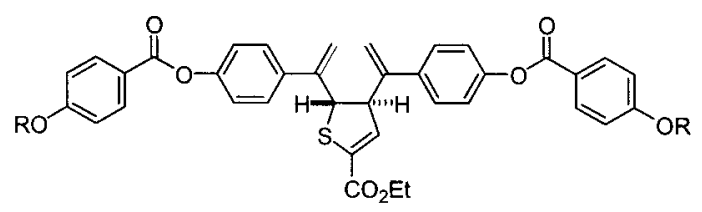

3h, $\mathrm{R}=\mathrm{C}_{10} \mathrm{H}_{21}, \mathrm{~K} 67.3^{\circ} \mathrm{C}, \mathrm{mp} 112.0^{\circ} \mathrm{C}$.

3i, $\mathrm{R}=\mathrm{C}_{12} \mathrm{H}_{25}, \mathrm{~K} 55.4^{\circ} \mathrm{C}, \mathrm{mp} 97.5^{\circ} \mathrm{C}$.

3j, $\mathrm{R}=\mathrm{C}_{14} \mathrm{H}_{29}, \mathrm{~K} 47.4^{\circ} \mathrm{C}, \mathrm{mp} 83.2^{\circ} \mathrm{C}$.

3k, $\mathrm{R}=\mathrm{C}_{16} \mathrm{H}_{33}, \mathrm{mp} 40^{\circ} \mathrm{C}$.

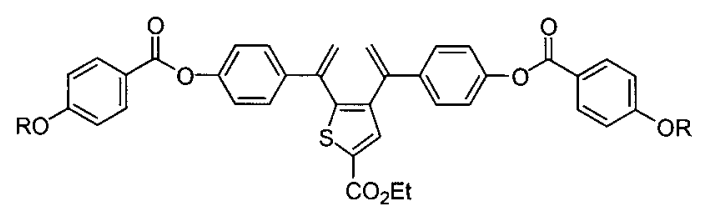

4h, $\mathrm{R}=\mathrm{C}_{10} \mathrm{H}_{21}, \mathrm{~K} 72.3^{\circ} \mathrm{C}, \mathrm{mp} 119.2^{\circ} \mathrm{C}$.

4i, $R=\mathrm{C}_{12} \mathrm{H}_{25}, K 59.8^{\circ} \mathrm{C}, \mathrm{mp} 109.5^{\circ} \mathrm{C}$.

4j, $R=\mathrm{C}_{14} \mathrm{H}_{29}, K 52.5^{\circ} \mathrm{C}, \mathrm{mp} 100.3^{\circ} \mathrm{C}$.

4k, R $=\mathrm{C}_{16} \mathrm{H}_{33}, K 67.0^{\circ} \mathrm{C}, \mathrm{mp} 99.8^{\circ} \mathrm{C}$.<smiles>[R]Oc1ccc(C(=O)Oc2ccc(-c3ccc(-c4ccc(OC(=O)c5ccc([R])cc5)cc4)c4sc(C(=O)OCC)cc34)cc2)cc1</smiles>

5h, $\mathrm{R}=\mathrm{C}_{10} \mathrm{H}_{21}, \mathrm{mp} 195.6^{\circ} \mathrm{C}$.

5i, $\mathrm{R}=\mathrm{C}_{12} \mathrm{H}_{25}, \mathrm{mp} 187.5^{\circ} \mathrm{C}$.

5j, $\mathrm{R}=\mathrm{C}_{14} \mathrm{H}_{29}, \mathrm{mp} 184.7^{\circ} \mathrm{C}$.

5k, R $=\mathrm{C}_{16} \mathrm{H}_{33}, \mathrm{mp} 188.5^{\circ} \mathrm{C}$.

Benzothiophenes bearing two thienyl substituents at the C-4 and C-7 positions, e.g., 7a-c and $\mathbf{8}$, were also prepared by using appropriate acetylthiophenes as the starting materials for the similar three-step reaction 
sequence. Compound $\mathbf{7 b}$ having bromine atoms on the thienyl rings is especially versatile because it can be elaborated by coupling with arenes, heterocyclic arenes, alkenes, and alkynes, e.g., via Heck, Stille, Suzuki and Sonogashira reactions, ${ }^{15}$ to construct various useful conjugated systems, including the oligo- and polymeric derivatives of $\mathbf{7 b}$.

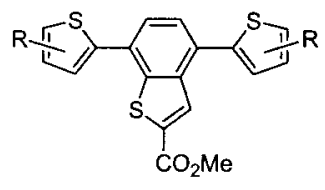

7a $\mathrm{R}=\mathrm{H}$

$7 \mathrm{~b} \mathrm{R}=5-\mathrm{Br}$

7c $\mathrm{R}=3-\mathrm{Me}$

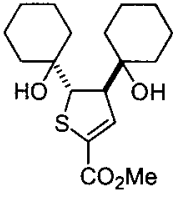

9a $(91 \%)$

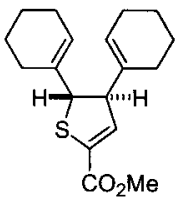

10a (88\%)

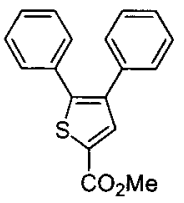

11 a $(89 \%)$

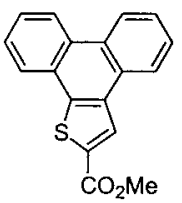

12a $(86 \%)$

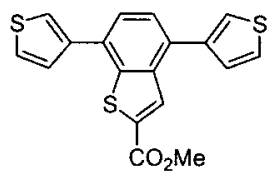

8

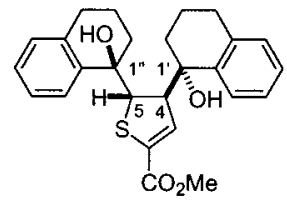

9b $(68 \%)$

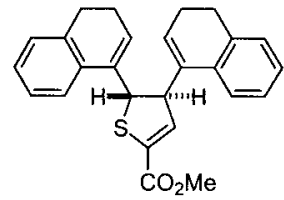

$10 \mathrm{~b}(97 \%)$

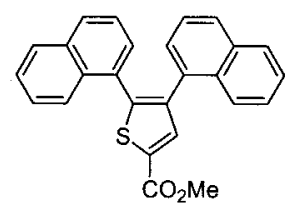

11b (94\%)

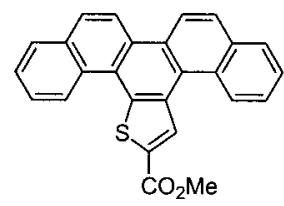

12b (89\%)
By the promotion of $\mathrm{Sml}_{2}$, $\mathbf{1 a}$ reacted with 2 equiv of cyclohexanone to give diol $9 a$ in $91 \%$ yield. The trans configuration of 9a was confirmed by its crystal structure, and the two hydroxyl groups were shown to have the axial orientations. As lanthanoid ion (e.g., $\mathrm{Sm}^{3+}$ ) is oxophilic and less basic than alkali and alkaline metal ions, ${ }^{16}$ additions of organosamarium species (e.g., the samarium dienolate $\mathbf{A}$ ) to the enolizable ketones (e.g.,

(13) Schoning, A.; Debaerdemaeker, T.; Zander, M.; Friedrichsen, W. Chem. Ber. 1989, 122, 1119.

(14) (a) Miyake, S.; Kusabayashi, S.; Takenaka, S. Bull. Chem. Soc. J pn. 1984, 57, 2404. (b) Brown, J. W.; Byron, D. J .; Harwood: D. J .; Wilson, R. C.; Tajbakhsh, A. R. Mol. Cryst. Liq. Cryst. 1989, 173, 121.

(15) (a) Kalinin, V. N. Synthesis 1992, 413. (b) Zhang, F.-J .; Cortez, C.; Harvey, R. G. J . Org. Chem. 2000, 65, 3952.

(16) (a) Molander, G. A. In ComprehensiveOrganic Synthesis; Trost, B. M., Fleming, I., Eds.; Pergamon Press: Oxford, 1991; Vol. 1, pp $251-$ 282. (b) Molander, G. A. Chem. Rev. 1992, 92, 29. (c) Imamoto, T. Lanthanides in Organic Synthesis; Academic Press: London, 1994. $\alpha$-tetralone and $\alpha$-phenylacetophenones) were realized. The $\mathrm{Sml}_{2}$-promoted reaction of $\mathbf{1 a}$ with tetral one gave diol $\mathbf{9 b}$ as a single isomer. Its rel ative configuration was determined to be $\left(4 R^{*}, 5 S^{*}, 1^{\prime} S^{*}, 1^{\prime \prime} R\right)$ by $\mathrm{X}$-ray analysis. The acid-catalyzed dehydration of $\mathbf{9 a}$ and $\mathbf{9 b}$ gave the corresponding dienes $\mathbf{1 0 a}$ and $\mathbf{1 0 b}$. Treatment of $\mathbf{1 0 a}$ with excess amounts (6.5 equiv) of DDQ in refluxing xylene gave diphenylthiophene 11a (89\% yield), instead of the cyclization compound 12a. Phenanthrothiophene $12 a^{5 b}$ was finally obtained by irradiation (300-nm light) of 11a in the presence of iodine. ${ }^{6 c, d, h, 17}$ By a similar procedure, dehydrogenation of $\mathbf{1 0 b}$ with DDQ (4.5 equiv) in refluxing toluene gave dinaphthylthiophene $\mathbf{1 1 b}(94 \%$ yield), and the subsequent photochemical reaction (300$\mathrm{nm}$ light, 1 equiv $\mathrm{I}_{2}$ ) gave picenothiophene $\mathbf{1 2 b}$ (89\% yield).

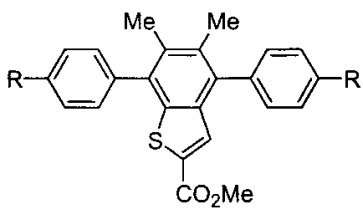

13a, $R=H(42 \%$ for 3 steps $)$

$13 \mathrm{~b}, \mathrm{R}=\mathrm{OMe}(23 \%$ for 3 steps $)$

A variety of 4,5,6,7-tetrasubstituted benzothiophenes such as $\mathbf{1 3 a}, \mathbf{b}$ and $\mathbf{1 4 a -}$ - were also synthesized via the following three-step reaction sequence: (i) using propiophenones or $\alpha$-phenylacetophenones to couple with thiophene-2-carboxylate, (ii) using p-TsOH to catalyze dehydration, and (iii) using excess DDQ to mediate the consecutive processes of dehydrogenation, electrocyclization, and oxidative aromatization. In the case of 13a, a photochemical oxidative aromatization was also applied. Tetraphenyl benzothiophenes $\mathbf{1 4 a}$ and $\mathbf{1 4 b}$ underwent the oxidative annulations by treatment with $\mathrm{AlCl}_{3} / \mathrm{CuCl}_{2} /$ $\mathrm{O}_{2}{ }^{18 a, b}$ or $\mathrm{FeCl}_{3}$, ${ }^{18 c}$ giving tribenzopentaphenothiophenes 15a and $\mathbf{1 5 b}$ in $91 \%$ and $79 \%$ yields.

Tetraanisole 14d was demethylated by $\mathrm{BBr}_{3}$ to give tetraphenol $\mathbf{1 4 e}$ in $74 \%$ yield. Alkylation of $\mathbf{1 4 e}$ with 1-bromooctane, 1-bromodecane, and 1-bromododecane gave acids $\mathbf{1 4 f}-\mathbf{h}$ because of the concurrent saponification in the presence of $\mathrm{KOH}$ (Scheme 4). The long alkyl chains were introduced to the radial-type benzothiophenes as these acids might form dimeric assembly via hydrogen bondings to render a discotic liquid-crystalline property. ${ }^{19}$ However, acids $\mathbf{1 4 f}-\mathbf{h}$ turn out to be crystalline compounds. None of them exhibit the desired liquid crystal properties.

In summary, we have developed a three-step procedure for the preparation of polysubstituted benzothiophenes (e.g., 5a-k, 7a-c, 13a,b, and $\mathbf{1 4 a}-\mathbf{d}$ ) and the related sulfur-containing polycyclic aromatic compounds (e.g., $\mathbf{1 2} \mathbf{a}, \mathbf{b}$ and $\mathbf{1 5 a}, \mathbf{b})$. By the promotion of $\mathrm{Sml}_{2}$, thiophene2-carboxylate underwent a double-electrophilic reaction

(17) (a) Baldwin, L. J .; Tedjamulia, M. L.; Stuart, J . G.; Castle, R N.; Lee, M. L. J . Heterocycl. Chem. 1984, 21, 1775. (b) Fischer, E.; Larsen, J .; Christensen, J. B.; Fourmigue, M.; Madsen, H. G.; Harrit, N. J . Org. Chem. 1996, 61, 6997.

(18) (a) Kovacic, P.: J ones, M. B. Chem. Rev. 1987, 87, 357. (b) Muller, M.; Mauermann-Dull, H.; Wagner, M.; Enkelmann, V.; Müllen, K. Angew. Chem., Int. Ed. Engl. 1995, 34, 1583. (c) Dötz, F.; Brand, J. D.; I to, S.; Gherghel, L.; Müllen, K.J . Am. Chem. Soc. 2000, 122, 7707.

(19) Kleppinger, R.; Lillya, C. P.; Yang, C. J . Am. Chem. Soc. 1997, 119, 4097. 
SCHEME 4. Synthesis of 4,5,6,7-Tetraphenylbenzo[b]thiophenes 14a-h, and the Fan-Shaped Polycyclic Aromatics 15a,b

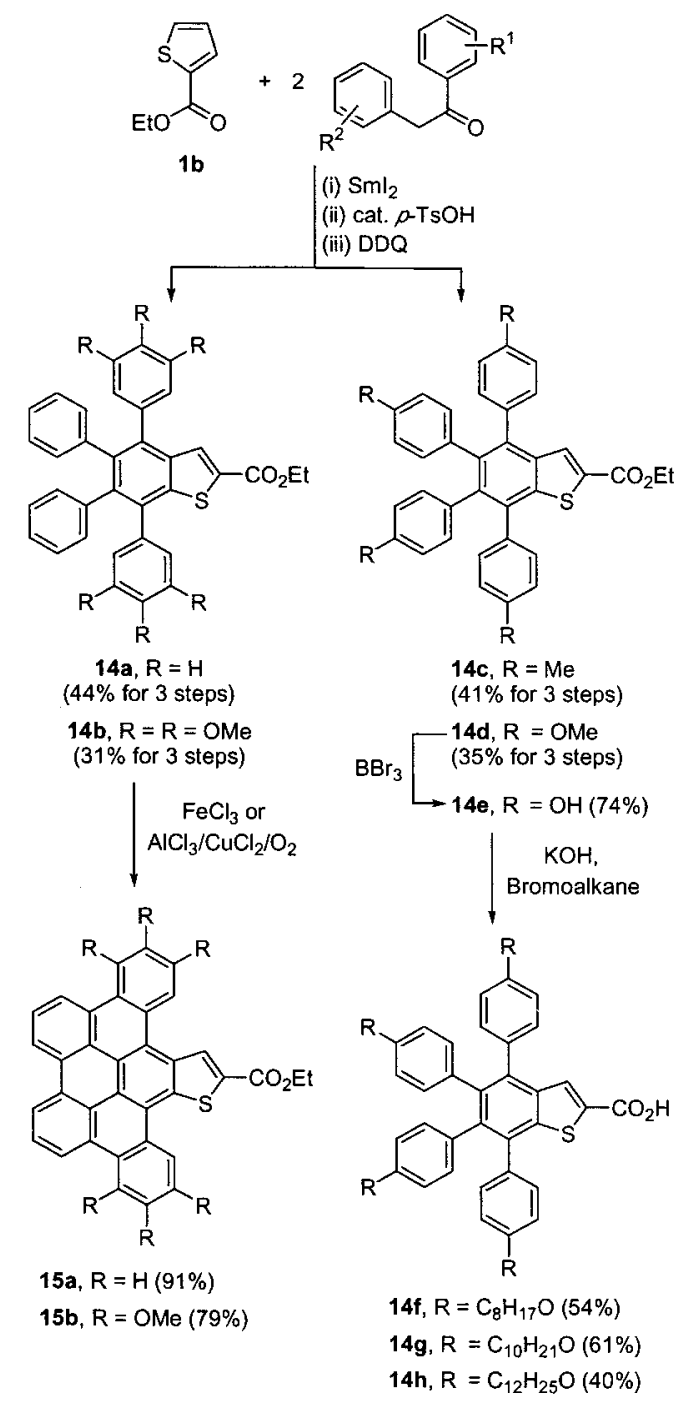

effectively with a variety of ketones, including the enolizable ketones (e.g., tetralone and $\alpha$-phenylacetophenones), to give the desired diol products (e.g., $2 \mathbf{a}-\mathbf{e}$ ). Dehydration of the diol products was accomplished by the catalysis of $\mathrm{p}-\mathrm{TsOH}$ to afford a series of dialkenyldihydrothiophenes (e.g., $\mathbf{3 a}-\mathbf{k}$ and $\mathbf{1 0 a}, \mathbf{b})$. For synthetic purposes, dialkenyldihydrothiophenes $\mathbf{3 a}-\mathbf{k}$ were directly converted to 4,7-diaryl benzothiophenes $\mathbf{5 a}-\mathbf{k}$ by treatment with excess amounts of DDQ in refluxing toluene. The intermediary dialkenylthiophenes (e.g., $\mathbf{4 b}$ and $\mathbf{4 f}-\mathbf{k}$ ) were obtained under mild reaction conditions (1 equiv of DDQ in benzene, $60{ }^{\circ} \mathrm{C}$ ). Compounds $\mathbf{3 h}-\mathbf{j}$ and $\mathbf{4 h}-\mathbf{k}$ bearing long-chain alkoxyphenyl substituents are liquid crystals of smectic-A type. Phenanthrothiophene 12a, picenothiophene $\mathbf{1 2} \mathbf{b}$, and tribenzopentaphenothiophenes $\mathbf{1 5 a}$ and $\mathbf{1 5 b}$ were obtained by chemical or photochemical oxidative annulations of diphenylthiophene 11a, dinaphthylthiophene $\mathbf{1 1} \mathbf{b}$, and tetraphenylbenzothiophenes 14a and 14b. The polycyclic aromatic compounds $\mathbf{1 2 a} \mathbf{a} \mathbf{b}$ and $\mathbf{1 5} \mathbf{a}, \mathbf{b}$ may be used as DNA intercalators as they exhibit characteristic planar structures similar to those of PAHs. ${ }^{2}$ As $\mathbf{1 2} \mathbf{a}, \mathbf{b}$ and $\mathbf{1 5 a}, \mathbf{b}$ are fluorescent compounds, their interactions with DNA can be monitored by the change of fluorescence intensity. The ester groups in 12a,b and $\mathbf{1 5 a} \mathbf{a}, \mathbf{b}$ can be modified, e.g., by transformation into carboxylic acids and other functional derivatives, to improvetheir chemical and physical properties, e.g., the water solubility and the sequence specificity in DNA recognition. F urthermore, incorporation of sulfur atom in these polycyclic aromatics can provide an opportunity for photochemical activation. We are currently exploring the interaction of picenothiophene 12b with calf thymus DNA and the possible cleavage of DNA double helix by photochemical activation.

Heterosuperbenzenes such as the nitrogen-functionalized graphite molecules ${ }^{20 a}$ are interesting research subjects. As we have previously demonstrated that indolecarbonyl coupling reactions are feasible by the promotion of $\mathrm{Sml}_{2}{ }^{20 \mathrm{~b}}$ we plan to explore further the nitrogencontaining polyaromatic systems, such as those derived from pyrroles, by using an approach similar to that described in this paper.

\section{Experimental Section}

General Methods. All reactions requiring anhydrous conditions were conducted in a flame-dried apparatus under an atmosphere of nitrogen. Syringes and needles for the transfer of reagents were dried at $100{ }^{\circ} \mathrm{C}$ and al lowed to cool in a desiccator over $\mathrm{P}_{2} \mathrm{O}_{5}$ before use. Ethers were distilled from sodium benzophenone ketyl; (chlorinated) hydrocarbons, and amines from $\mathrm{CaH}_{2}$. Reactions were monitored by TLC using plates precoated with a $0.25 \mathrm{~mm}$ layer of silica gel containing a fluorescent indicator (Merck Art. 5544). Column chromatography was carried out on Kieselgel $60(40-63 \mu \mathrm{m})$. The photochemical reactions were conducted in a Rayonet photochemical reactor using 300-nm lamps.

Melting points are uncorrected. Chemical shifts of ${ }^{1} \mathrm{H}$ and ${ }^{13} \mathrm{C} N M R$ spectra are reported relative to $\mathrm{CHCl}_{3}\left[\delta_{\mathrm{H}} 7.24, \delta_{\mathrm{C}}\right.$ (central line of t) 77.0]. Coupling constants $(J)$ are given in $\mathrm{Hz}$. Distortionless enhancement polarization transfer (DEPT) spectra were taken to determine the types of carbon signals.

Representative Procedure for the $\mathrm{Sml}_{2}$-Promoted Coupling Reactions of Thiophene-2-carboxylate with 2 equiv of Aryl Ketones, Giving Diols 2. Caution: HMPA is suspected as a carcinogen. Handle HMPA with care. Under an atmosphere of argon, a deep blue $\mathrm{Sml}_{2}$ solution $(0.1 \mathrm{M})$ was prepared by treatment of Sm (661 mg, $4.4 \mathrm{mmol}$ ) with 1,2diiodoethane $(1.01 \mathrm{~g}, 3.6 \mathrm{mmol})$ in anhydrous HMPA $(2.8 \mathrm{~mL}$, $16 \mathrm{mmol}$ ) and THF ( $35 \mathrm{~mL}$ ) for $1.5 \mathrm{~h}$ at room temperature ( 25 ${ }^{\circ} \mathrm{C}$ ). To the $\mathrm{Sml}{ }_{2}$ solution (cooled in an ice bath) were added a THF solution ( $3 \mathrm{~mL}$ ) of methyl thiophene-2-carboxylate (142 $\mathrm{mg}, 1.0 \mathrm{mmol}$ ) and acetophenone (252 $\mathrm{mg}, 2.1 \mathrm{mmol})$. The reaction mixture was stirred at $0{ }^{\circ} \mathrm{C}$ for $20 \mathrm{~min}$ and then at room temperature for $2-10 \mathrm{~h}$. The reaction was quenched by addition of saturated aqueous $\mathrm{NH}_{4} \mathrm{Cl}$ solution $(1 \mathrm{~mL})$. The mixture was passed through a short silica gel column by rinsing with EtOAc/hexane (1:1). The filtrate was concentrated and chromatographed on a silica gel column by elution with EtOAc/hexane $(2: 8)$ to give the desired three-component coupling product 2 a (233 mg, 61\%). Two diastereomers (42: 58) were separable on the silica gel column. The less polar isomer corresponded to the minor isomer.

Representative Procedure for Dehydration of Diols 2, Giving Dienes 3. Diol 2a (300 mg, $0.78 \mathrm{mmol}$ ) and $\mathrm{p}-\mathrm{TsOH}$ (catalytic amount) in benzene $(30 \mathrm{~mL}$ ) were heated at reflux for 5-12 h, while a Dean-Stark apparatus removed the generated water azeotropically. The reaction mixture was concentrated under reduced pressure and chromatographed

(20) (a) Draper, S. M.; Gregg, D. J .; Madathil, R. J . Am. Chem. Soc. 2002, 124, 3486. (b) Lin, S.-C.; Y ang, F.-D.; Shiue, J .-S.; Yang, S.-M.; Fang, J.-M. J . Org. Chem. 1998, 63, 2909. 
on a silica gel column by elution with EtOAc/hexane (1:9) to afford the corresponding diene $3 \mathbf{a}$ (245 mg, 90\%).

Representative Procedure for DDQ Oxidation of Dienes 3, Giving 4,5-Dialkenylthiophenes 4 and 4,7Diarylbenzothiophenes 5. A mixture of diene $\mathbf{3 b}$ (140 mg, $0.34 \mathrm{mmol}$ ) and DDQ (92 $\mathrm{mg}, 0.40 \mathrm{mmol}$ ) in anhydrous benzene $(10 \mathrm{~mL})$ was heated at $60^{\circ} \mathrm{C}$ for $10-12 \mathrm{~h}$. The reaction mixture was concentrated under reduced pressure and chromatographed on a silica gel column by elution with EtOAc hexane (2:8) to give thiophene $\mathbf{4 b}$ (125 $\mathrm{mg}, 89 \%$ ). On the other hand, diene $3 a(290 \mathrm{mg}, 0.70 \mathrm{mmol})$ was reacted with excess amounts of DDQ (352 mg, $1.55 \mathrm{mmol}$ ) in refluxing toluene (15 $\mathrm{mL}$ ) for 7-18 h to give benzothiophene $5 \mathbf{b}$ (262 mg, 91\%).

Representative Procedure for Oxidative Cyclization under Photochemical Conditions. Diarylthiophene 11a (30 $\mathrm{mg}, 0.1 \mathrm{mmol}$ ) and iodine ( $26 \mathrm{mg}, 0.1 \mathrm{mmol}$ ) in deoxygenated anhydrous benzene $(20 \mathrm{~mL})$ were placed in a quartz tube equipped with a cooling circulation of ice-water. The solution was irradiated by $300-\mathrm{nm}$ light in a Rayonet photochemical reactor for $20 \mathrm{~h}$. The mixture was concentrated, treated with aqueous $\mathrm{Na}_{2} \mathrm{~S}_{2} \mathrm{O}_{3}$ to remove the remaining iodine, and extracted with $\mathrm{CH}_{2} \mathrm{Cl}_{2}(3 \times)$. The organic phase was dried $\left(\mathrm{Na}_{2-}\right.$ $\left.\mathrm{SO}_{4}\right)$ and concentrated. Pure polyaromatic product $\mathbf{1 2 a}(86 \%$ yield) was obtained by crystallization from $\mathrm{CH}_{2} \mathrm{Cl}_{2} /$ hexane or by chromatography on a silica gel column with elution of EtOAc/hexane (1:9).

Methyl 4,5-Bis(I-hydroxy-I-phenylethyl)-4,5-dihydrothiophene-2-carboxylate (2a). 2a, minor isomer: oil; TLC (EtOAc/hexane, 3:7) $\mathrm{R}_{\mathrm{f}}=0.21$; IR (neat) $3452,1710 \mathrm{~cm}^{-1}$; ${ }^{1} \mathrm{H}$ NMR $\left(\mathrm{CDCl}_{3}, 200 \mathrm{MHz}\right) \delta$ 7.47-7.18 $(10 \mathrm{H}, \mathrm{m}), 6.21(1 \mathrm{H}, \mathrm{d}$, $\mathrm{J}=3.6 \mathrm{~Hz}), 4.03(1 \mathrm{H}, \mathrm{d}, \mathrm{J}=3.1 \mathrm{~Hz}), 3.71(3 \mathrm{H}, \mathrm{s}), 3.61(1 \mathrm{H}$ $\mathrm{dd}, \mathrm{J}=3.6,3.1 \mathrm{~Hz}), 2.70(1 \mathrm{H}, \mathrm{br} \mathrm{s}, \mathrm{OH}), 2.35(1 \mathrm{H}, \mathrm{br} \mathrm{s}, \mathrm{OH})$, $1.65(3 \mathrm{H}, \mathrm{s}), 1.16(3 \mathrm{H}, \mathrm{s}) ;{ }^{13} \mathrm{C} N M R\left(\mathrm{CDCl}_{3}, 75 \mathrm{MHz}\right) \delta 162.3$, $145.2,143.9,135.1,134,5,128.2(2 \times), 128.1(2 \times), 127.4,126.8$, $125.9(2 \times), 124.7(2 \times), 76.4(2 \times), 61.7,60.7,52.3,27.7,26.1$ FAB-MS m/z $367.0\left(\mathrm{M}^{+}+1-\mathrm{H}_{2} \mathrm{O}\right)$; HRMS calcd for $\mathrm{C}_{22} \mathrm{H}_{24} \mathrm{O}_{4} \mathrm{~S}$ 384.1396, found 384.1391. 2a, major isomer: oil; TLC (EtOAC hexane, 3:7) $\mathrm{R}_{\mathrm{f}}=0.18$; IR (neat) $3480 \mathrm{~cm}^{-1} ;{ }^{1} \mathrm{H} \mathrm{NMR}\left(\mathrm{CDCl}_{3}\right.$, $200 \mathrm{MHz}) \delta 7.41-7.21(10 \mathrm{H}, \mathrm{m}), 6.23(1 \mathrm{H}, \mathrm{d}, \mathrm{J}=3.5 \mathrm{~Hz})$, $4.23(1 \mathrm{H}, \mathrm{d}, \mathrm{J}=3.0 \mathrm{~Hz}), 3.67(3 \mathrm{H}, \mathrm{s}), 3.65(1 \mathrm{H}, \mathrm{dd}, \mathrm{J}=3.5$, $3.0 \mathrm{~Hz}), 2.86(1 \mathrm{H}, \mathrm{s}, \mathrm{OH}), 2.41(1 \mathrm{H}, \mathrm{s}, \mathrm{OH}), 1.45(3 \mathrm{H}, \mathrm{s}), 1.31$ $(3 \mathrm{H}, \mathrm{s}) ;{ }^{13} \mathrm{C} \mathrm{NMR}\left(\mathrm{CDCl}_{3}, 75 \mathrm{MHz}\right) \delta 162.2,145.5,145.4,135.4$, 134.6, $128.3(2 \times), 128.2(2 \times), 127.2(2 \times), 125.3(2 \times), 125.1$ (2x), 76.8, 76.3, 61.3, 60.6, 52.3, 26.6, 25.0; FAB-MS m/z 367.0 $\left(\mathrm{M}^{+}+1-\mathrm{H}_{2} \mathrm{O}\right)$; HRMS calcd for $\mathrm{C}_{22} \mathrm{H}_{24} \mathrm{O}_{4} \mathrm{~S} 384.1396$, found 384.1398.

Methyl 4,5-Bis[1-(4-octadecanoyloxy)phenylethenyl]4,5-dihydrothiophene-2-carboxylate (3g). According to the representative procedure, the $\mathrm{Sml}_{2}$-promoted coupling reaction of la with 4-acetylphenyl stearate, followed by the acidcatalyzed dehydration, gave diene $\mathbf{3 g}$ in $48 \%$ overall yield: solid; $\mathrm{mp} 84-85^{\circ} \mathrm{C}$; TLC (EtOAc/hexane, $\left.1: 9\right) \mathrm{R}_{\mathrm{f}}=0.34$; IR $(\mathrm{KBr}) 1754,1727 \mathrm{~cm}^{-1} ;{ }^{1} \mathrm{H}$ NMR $\left(\mathrm{CDCl}_{3}, 200 \mathrm{MHz}\right) \delta 7.22(2$ $\mathrm{H}, \mathrm{d}, \mathrm{J}=8.6 \mathrm{~Hz}), 7.16(2 \mathrm{H}, \mathrm{d}, \mathrm{J}=8.6 \mathrm{~Hz}), 6.96(2 \mathrm{H}, \mathrm{d}, \mathrm{J}=$ $8.6 \mathrm{~Hz}), 6.95(2 \mathrm{H}, \mathrm{d}, \mathrm{J}=8.6 \mathrm{~Hz}), 6.51(1 \mathrm{H}, \mathrm{d}, \mathrm{J}=3.1 \mathrm{~Hz})$, $5.40(1 \mathrm{H}, \mathrm{s}), 5.32(1 \mathrm{H}, \mathrm{s}), 5.27(1 \mathrm{H}, \mathrm{s}), 5.17(1 \mathrm{H}, \mathrm{s}), 4.67(1$ $\mathrm{H}, \mathrm{d}, \mathrm{J}=6.7 \mathrm{~Hz}), 4.30(1 \mathrm{H}, \mathrm{dd}, \mathrm{J}=6.7,3.1 \mathrm{~Hz}), 3.78(3 \mathrm{H}, \mathrm{s})$, $2.52(4 \mathrm{H}, \mathrm{t}, \mathrm{J}=7.3 \mathrm{~Hz}), 1.71(4 \mathrm{H}$, quint, $\mathrm{J}=7.3 \mathrm{~Hz}), 1.33-$ $1.24(56 \mathrm{H}, \mathrm{br} \mathrm{s}) .0 .86(6 \mathrm{H}, \mathrm{t}, \mathrm{J}=6.7 \mathrm{~Hz}) ;{ }^{13} \mathrm{C} \mathrm{NMR}\left(\mathrm{CDCl}_{3}\right.$, $125 \mathrm{MHz}) \delta 172.1(2 \times), 162.7,150.4(2 \times), 146.9,145.8,137.4$, $137.3,135.0,134.9,128.4(2 \times), 127.7(2 \times), 121.6(2 \times), 121.4$ $(2 \times), 115.9,115.2,58.1(2 \times), 52.4,34.4(2 \times), 31.9(2 \times), 29.67$ $(12 \times), 29.64(2 \times), 29.60(2 \times), 29.4(2 \times), 29.3(2 \times), 29.2(2 \times)$, $29.1(2 \times), 24.9(2 \times), 22.6(2 \times), 14.1(2 \times)$; FAB-MS m/z 913.6 $\left(\mathrm{M}^{+}+1\right)$. Anal. Calcd for $\mathrm{C}_{58} \mathrm{H}_{88} \mathrm{O}_{6} \mathrm{~S}$ : C, 76.26; $\mathrm{H}, 9.72$. Found: C, 75.96; $\mathrm{H}, 9.74$.

Ethyl 4,5-bis[1-(naphth-2-yl)-2-methylpropenyl]thiophene-2-carboxylate (4I): oil; TLC (EtOAc/hexane (1:19)) $R_{f}$ $=0.13$; IR (neat) 1705, $1617 \mathrm{~cm}^{-1}$; UV $\left(\mathrm{CHCl}_{3}\right) \lambda_{\max }(\epsilon) 290$ $\mathrm{nm}$ (35400), $364 \mathrm{~nm}$ (17100); FL $\left(\mathrm{CHCl}_{3}, \mathrm{C}=2 \times 10^{-5} \mathrm{M}\right) \lambda_{\mathrm{em}}$ $415 \mathrm{~nm}$ by excitation at $364 \mathrm{~nm}$; ${ }^{1} \mathrm{H} \mathrm{NMR}\left(\mathrm{CDCl}_{3}, 300 \mathrm{MHz}\right)$

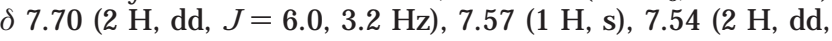

$\mathrm{J}=6.0,3.2 \mathrm{~Hz}), 7.37-7.34(6 \mathrm{H}, \mathrm{m}), 7.00-6.95(4 \mathrm{H}, \mathrm{m}), 4.29$ $(2 \mathrm{H}, \mathrm{q}, \mathrm{J}=6.2 \mathrm{~Hz}), 1.69(3 \mathrm{H}, \mathrm{s}), 1.67(3 \mathrm{H}, \mathrm{s}), 1.60(3 \mathrm{H}, \mathrm{s})$, $1.57(3 \mathrm{H}, \mathrm{s}), 1.33(3 \mathrm{H}, \mathrm{t}, \mathrm{J}=6.2 \mathrm{~Hz}) ;{ }^{13} \mathrm{C} \mathrm{NMR}\left(\mathrm{CDCl}_{3}, 75\right.$ $\mathrm{MHz}) \delta 162.5,148.1,141.8,139.5,139.0,137.9,136.5,134.3$, $133.1,132.0(2 \times), 131.8,131.1,131.0,128.8(2 \times), 128.7(2 \times)$, $128.1,127.9,127.8,127.7,127.4,127.0,126.8,125.8,125.7$, $125.5,125.4,60.9,22.8,22.5,22.3,21.9,14.4$; FAB-MS 516.2 $\left(\mathrm{M}^{+}\right)$; HRMS calcd for $\mathrm{C}_{35} \mathrm{H}_{32} \mathrm{O}_{2} \mathrm{~S} 516.2123$, found 516.2122. Anal. Calcd for $\mathrm{C}_{35} \mathrm{H}_{32} \mathrm{O}_{2} \mathrm{~S}$ : C, 81.36; $\mathrm{H}, 6.24$. Found: $\mathrm{C}, 81.62$; $\mathrm{H}, 6.36$.

Methyl 7-(4-Chlorophenyl)-4-(4-methoxyphenyl)benzo[b]thiophene-2-carboxylate (5f). A mixture of methyl thiophene-2-carboxylate (142 $\mathrm{mg}, 1.0 \mathrm{mmol}$ ) and 4-chloroacetophenone (155 mg, $1.0 \mathrm{mmol})$ in THF $(2 \mathrm{~mL})$ was treated with $\mathrm{Sml}_{2} / \mathrm{HMPA}(3.6 / 16.0 \mathrm{mmol})$ at $0{ }^{\circ} \mathrm{C}$ for $10 \mathrm{~min}$ and at $25^{\circ} \mathrm{C}$ for $2 \mathrm{~h}$. The second el ectrophile of 4-methoxyacetophenone (180 $\mathrm{mg}, 1.2 \mathrm{mmol}$ ) was added dropwise. The reaction mixture was stirred at room temperature for $14 \mathrm{~h}$ and then worked up to give the diol product $\mathbf{2 f}$ according to the representative procedure. The subsequent acid-catalyzed dehydration gave diene $\mathbf{3 f}$ in $51 \%$ overall yield. The reaction of diene $\mathbf{3 k}$ with 2.2 equiv of DDQ in refluxing tol uene gave benzothiophene $5 \mathbf{f}$ in $85 \%$ yield: solid; $\mathrm{mp} 201-202{ }^{\circ} \mathrm{C}$; TLC (EtOAc/hexane, 1:9) $\mathrm{R}_{\mathrm{f}}=0.23$; IR $(\mathrm{KBr}) 1723 \mathrm{~cm}^{-1}$; UV $\left(\mathrm{CHCl}_{3}\right) \lambda_{\max }(\epsilon) 282 \mathrm{~nm}$ (61600), $347 \mathrm{~nm}$ (24000); $\mathrm{FL}\left(\mathrm{CHCl}_{3}, \mathrm{C}=2 \times 10^{-4} \mathrm{M}\right) \lambda_{\mathrm{em}} 435$ $\mathrm{nm}$ by excitation at $347 \mathrm{~nm}$; ${ }^{1} \mathrm{H}$ NMR $\left(\mathrm{CDCl}_{3}, 200 \mathrm{MHz}\right) \delta 8.21$ $(1 \mathrm{H}, \mathrm{s}), 7.65(2 \mathrm{H}, \mathrm{dd}, \mathrm{J}=8.6,2.0 \mathrm{~Hz}), 7.50-7.40(6 \mathrm{H}, \mathrm{m})$, $7.04(2 \mathrm{H}, \mathrm{dd}, \mathrm{J}=8.6,2.0 \mathrm{~Hz}), 3.89(3 \mathrm{H}, \mathrm{s}), 3.88(3 \mathrm{H}, \mathrm{s}) ;{ }^{13} \mathrm{C}$ NMR $\left(\mathrm{CDCl}_{3}, 75 \mathrm{MHz}\right) \delta 163.1,159.5,141.8,138.9,138.2$, $137.9,134.3,134.2,133.2,132.2,130.7,130.2(2 \times), 129.5(2 \times)$, $129.4(2 \times), 127.0,125.9,114.2(2 \times), 55.4,52.5$; FAB-MS m/z $407.9\left(\mathrm{M}^{+}\right)$; $\mathrm{HRMS}$ calcd for $\mathrm{C}_{23} \mathrm{H}_{17} \mathrm{ClO}_{3} \mathrm{~S}$ 408.0587, found 408.0583. Anal. Calcd for $\mathrm{C}_{23} \mathrm{H}_{17} \mathrm{ClO}_{3} \mathrm{~S}$ : C, 67.64; $\mathrm{H}, 4.20$. Found: $\mathrm{C}, 67.21 ; \mathrm{H}, 4.36$.

Ethyl 6-Aza-4,8-di(naphth-2-yl)-5,7-dioxo-6-phenyl-1thiatetracyclo[7.3.2.4,80,3a,8a04a,7a]tetradeca-2,3a(8a)-diene2-carboxylate (6). A mixture of triene $\mathbf{4 e}(96 \mathrm{mg}, 0.2 \mathrm{mmol})$ and $\mathrm{N}$-phenylmaleimide (353 $\mathrm{mg}, 2.0 \mathrm{mmol}$ ) in deoxygenated anhydrous toluene $(15 \mathrm{~mL})$ was heated at reflux for $48 \mathrm{~h}$. The mixture was concentrated and chromatographed on a silica gel column by elution with EtOAc/hexane (2:8) to give an oxidative aromatization product 5 e $(73 \mathrm{mg}, 80 \%)$ and a DielsAlder addition product 6 (15 mg, 12\%). 6: oily solid; TLC (EtOAc/hexane (1:4)) $\mathrm{R}_{\mathrm{f}}=0.10 ;{ }^{1} \mathrm{H}$ NMR $\left(\mathrm{CDCl}_{3}, 300 \mathrm{MHz}\right) \delta$ $8.44(1 \mathrm{H}, \mathrm{s}), 8.33(1 \mathrm{H}, \mathrm{s}), 7.97-7.79(7 \mathrm{H}, \mathrm{m}), 7.78(1 \mathrm{H}, \mathrm{s})$, 7.52-7.48 (5 H, m), 7.21-7.18 (3 H, m), 6.69-6.66 (2 H, m), 4.34-4.33 $(2 \mathrm{H}, \mathrm{m}), 4.27(2 \mathrm{H}, \mathrm{q}, \mathrm{J}=7.2 \mathrm{~Hz}), 2.15-2.11(4 \mathrm{H}$, $\mathrm{m}), 1.28(3 \mathrm{H}, \mathrm{t}, \mathrm{J}=7.2 \mathrm{~Hz}) ;{ }^{13} \mathrm{C} \mathrm{NMR}\left(\mathrm{CDCl}_{3}, 100 \mathrm{MHz}\right) \delta$ $174.3,173.8,162.2,147.9,143.3,138.1,137.6,133.1,133.0$, $132.7,132.5,131.9,131.4,131.3,128.8,128.5,128.3,128.2$, $127.9,127.7(2 \times), 127.6,127.5(2 \times), 127.1,126.6(2 \times), 126.4$ $126.3,126.2,126.17,126.1,125.3,61.2,49.9,49.0,48.3,47.8$, 38.7, 38.6, 14.4. FAB-MS m/z 633.2 $\left(\mathrm{M}^{+}\right)$; HRMS calcd for $\mathrm{C}_{41} \mathrm{H}_{31} \mathrm{NO}_{4} \mathrm{~S}$ 633.1974, found 633.1968.

Methyl 4,7-Bis(5-bromo-2-thienyl)benzo[b]thiophene2-carboxylate (7b). According to the representative proce dure, the Sml 2 -promoted coupling reaction of 1a with 2-acetyl5-bromothiophene, foll owed by the acid-catalyzed dehydration and DDQ oxidative cyclization, gave benzothiophene $\mathbf{7 b}$ in $35 \%$ overall yield: solid; $\mathrm{mp} 145-147^{\circ} \mathrm{C}$; TLC (EtOAc/hexane, 1:19) $\mathrm{R}_{\mathrm{f}}=0.21$; IR $(\mathrm{KBr}) 1724 \mathrm{~cm}^{-1}$; UV $\left(\mathrm{CHCl}_{3}\right) \lambda_{\max }(\epsilon) 294 \mathrm{~nm}$ (14700), $333 \mathrm{~nm}$ (12300), $368 \mathrm{~nm}$ (11600); FL $\left(\mathrm{CHCl}_{3}, \mathrm{C}=1 \times\right.$ $\left.10^{-5} \mathrm{M}\right) \lambda_{\mathrm{em}} 461 \mathrm{~nm}$ by excitation at $368 \mathrm{~nm}$; ${ }^{1} \mathrm{H} \mathrm{NMR}\left(\mathrm{CDCl}_{3}\right.$, $200 \mathrm{MHz}) \delta 8.38(1 \mathrm{H}, \mathrm{s}), 7.52(1 \mathrm{H}, \mathrm{d}, \mathrm{J}=7.7 \mathrm{~Hz}), 7.43(1 \mathrm{H}$,

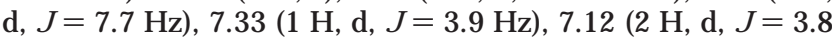
$\mathrm{Hz}), 7.07(1 \mathrm{H}, \mathrm{d}, \mathrm{J}=3.9 \mathrm{~Hz}), 3.94(3 \mathrm{H}, \mathrm{s}) ;{ }^{13} \mathrm{C} \mathrm{NMR}\left(\mathrm{CDCl}_{3}\right.$, $125 \mathrm{MHz}) \delta 162.8,142.7,142.6,140.8,137.4,134.2,130.8$, $130.75,130.73,130.0,128.6,127.0,126.23,126.19,126.0$, 113.13, 113.09, 52.7; EI-MS m/z (rel intensity) 516 (13, $\left.\mathrm{C}_{18} \mathrm{H}_{10}\left({ }^{81} \mathrm{Br}\right)_{2} \mathrm{O}_{2} \mathrm{~S}_{3}\right), 514$ (17), $512\left(10, \mathrm{C}_{18} \mathrm{H}_{10}\left({ }^{79} \mathrm{Br}\right)_{2} \mathrm{O}_{2} \mathrm{~S}_{3}\right), 91$ (100); HRMS calcd for $\mathrm{C}_{18} \mathrm{H}_{10}\left({ }^{81} \mathrm{Br}\right)_{2} \mathrm{O}_{2} \mathrm{~S}_{3}$ 515.8169, found 515.8168 . 
Methyl 4,5-Diphenylthiophene-2-carboxylate (11a). ACcording to the representative procedure, the reaction of diene $10 \mathrm{a}$ with 6.5 equiv of DDQ in refluxing xylene for $48 \mathrm{~h}$ gave diphenylthiophene 11 a in $89 \%$ yield: solid; $\mathrm{mp} 85-86{ }^{\circ} \mathrm{C}$; TLC (EtOAc/hexane, 1:9) $\mathrm{R}_{\mathrm{f}}=0.33$; IR $(\mathrm{KBr}) 1715 \mathrm{~cm}^{-1}$; UV $\left(\mathrm{CHCl}_{3}\right) \lambda_{\max }(\epsilon) 317 \mathrm{~nm}(48000) ; \mathrm{FL}\left(\mathrm{CHCl}_{3}, \mathrm{C}=1 \times 10^{-5} \mathrm{M}\right)$ $\lambda_{\mathrm{em}} 410 \mathrm{~nm}$ by excitation at $317 \mathrm{~nm}$; ${ }^{1} \mathrm{H} \mathrm{NMR}\left(\mathrm{CDCl}_{3}, 200\right.$ $\mathrm{MHz}) \delta 7.81(1 \mathrm{H}, \mathrm{s}), 7.31-7.19(10 \mathrm{H}, \mathrm{m}), 3.90(3 \mathrm{H}, \mathrm{s}) ;{ }^{13} \mathrm{C}$ $\mathrm{NMR}\left(\mathrm{CDCl}_{3}, 50 \mathrm{MHz}\right) \delta 162.6,145.6,138.8,136.2,135.4(2 \times)$, 133.3, 131.1, $129.2(2 \times), 128.9(2 \times), 128.6(2 \times), 128.4(2 \times)$, 128.3, 127.3; EI-MS m/z (rel intensity) 294 (100, M+); HRMS cal cd for $\mathrm{C}_{18} \mathrm{H}_{14} \mathrm{C}_{2} \mathrm{~S} 294.0715$, found 294.0721. Anal. Cal cd for $\mathrm{C}_{18} \mathrm{H}_{14} \mathrm{O}_{2} \mathrm{~S}$ : C, 73.45; $\mathrm{H}, 4.80$. Found: $\mathrm{C}, 73.29 ; \mathrm{H}, 4.67$.

Methyl Piceno[13,14-b]thiophene-2-carboxylate (12b). The photochemical reaction of dinaphthylthiophene $\mathbf{1 1 b}$ in the presence of $\mathrm{I}_{2}$, under conditions similar to that for $\mathbf{1 2 a}$, gave picenothiophene $\mathbf{1 2 b}$ in $89 \%$ yield: solid; $\mathrm{mp} 218-219^{\circ} \mathrm{C}$; TLC (EtOAc/hexane, 1:9) $\mathrm{R}_{\mathrm{f}}=0.22$; IR ( $\left.\mathrm{KBr}\right) 1712 \mathrm{~cm}^{-1}$; UV $\left(\mathrm{CHCl}_{3}\right)$ $\lambda_{\max }(\epsilon) 348 \mathrm{~nm}$ (25700), $365 \mathrm{~nm}$ (25200), $406 \mathrm{~nm}$ (8100); FL $\left(\mathrm{CHCl}_{3}, \mathrm{C}=1 \times 10^{-5} \mathrm{M}\right) \lambda_{\mathrm{em}} 416$ and $437 \mathrm{~nm}$ by excitation at $406 \mathrm{~nm} ;{ }^{1} \mathrm{H} \mathrm{NMR}\left(\mathrm{CDCl}_{3}, 300 \mathrm{MHz}\right) \delta 9.24(1 \mathrm{H}, \mathrm{d}, \mathrm{J}=8.5$ $\mathrm{Hz}), 9.09(1 \mathrm{H}, \mathrm{s}), 8.35(1 \mathrm{H}, \mathrm{d}, \mathrm{J}=8.2 \mathrm{~Hz}), 8.56(1 \mathrm{H}, \mathrm{d}, \mathrm{J}=$ $10 \mathrm{~Hz}), 8.52(1 \mathrm{H}, \mathrm{d}, \mathrm{J}=10 \mathrm{~Hz}), 7.98-7.92(3 \mathrm{H}, \mathrm{m}), 7.89(1$ $\mathrm{H}, \mathrm{d}, \mathrm{J}=8.5 \mathrm{~Hz}), 7.76(1 \mathrm{H}, \mathrm{td}, \mathrm{J}=8.0,1.2 \mathrm{~Hz}), 7.70-7.60(3$ $\mathrm{H}, \mathrm{m}), 4.00(3 \mathrm{H}, \mathrm{s}) ;{ }^{13} \mathrm{C} \mathrm{NMR}\left(\mathrm{CDCl}_{3}, 75 \mathrm{MHz}\right) \delta 163.2,139.4$, $134.2,133.1,132.8,132.5,131.8,129.6,129.3,129.0,128.8$, $128.4,128.3,127.5,127.4,127.3,127.2,126.8,126.7,126.6$, $126.2,125.6,125.0,121.7,121.3,52.5 ; \mathrm{MS} \mathrm{m} / \mathrm{z}$ (rel intensity) $392\left(14, \mathrm{M}^{+}\right)$, 91 (100); HRMS calcd for $\mathrm{C}_{26} \mathrm{H}_{16} \mathrm{O}_{2} \mathrm{~S} 392.0871$, found 392.0873. Anal. Calcd for $\mathrm{C}_{26} \mathrm{H}_{16} \mathrm{O}_{2} \mathrm{~S}$ : C, 79.57; $\mathrm{H} 4.11$. Found: C, 79.52, H 4.08 .

Ethyl 4,5,6,7-Tetraphenylbenzo[b]thiophene-2-carboxylate (14a). According to the representative procedure, the $\mathrm{Sml}_{2}$-promoted coupling reaction of ethyl thiophene-2-carboxylate (1b) with $\alpha$-phenylacetophenone, followed by acidcatalyzed dehydration and DDQ oxidative cyclization, gave tetraphenylbenzothiophene 14a in 44\% overall yield: solid; $\mathrm{mp}$ $>300{ }^{\circ} \mathrm{C}$; TLC (EtOAc/hexane, 1:4) $\mathrm{R}_{\mathrm{f}}=0.32$; IR (KBr) 1715 $\mathrm{cm}^{-1}$; UV $\left(\mathrm{CHCl}_{3}\right) \lambda_{\max }(\epsilon) 309 \mathrm{~nm}$ (50600), $345 \mathrm{~nm}$ (18900); $\mathrm{FL}\left(\mathrm{CHCl}_{3}, \mathrm{C}=1 \times 10^{-5} \mathrm{M}\right) \lambda_{\mathrm{em}} 399 \mathrm{~nm}$ by excitation at 345 $\mathrm{nm} ;{ }^{1} \mathrm{H} \mathrm{NMR}\left(\mathrm{CDCl}_{3}, 300 \mathrm{MHz}\right) \delta 7.86(1 \mathrm{H}, \mathrm{s}), 7.28-7.16(10$ $\mathrm{H}, \mathrm{m}), 6.89-6.80(10 \mathrm{H}, \mathrm{m}), 4.31(2 \mathrm{H}, \mathrm{q}, \mathrm{J}=7.2 \mathrm{~Hz}), 1.32(3$ $\mathrm{H}, \mathrm{t}, \mathrm{J}=7.2 \mathrm{~Hz}) ;{ }^{13} \mathrm{C} \mathrm{NMR}\left(\mathrm{CDCl}_{3}, 75 \mathrm{MHz}\right) \delta 153.8,139.5$ $(2 \times), 139.4(2 \times), 137.7(2 \times), 135.2(2 \times), 134.0(2 \times), 131.5(2 \times)$, $131.3(2 \times), 131.2(2 \times), 130.5(2 \times), 129.8(2 \times), 128.1(2 \times), 127.7$ $(2 \times), 127.3(2 \times), 126.8(2 \times), 125.8(2 \times), 125.6(2 \times), 61.5,14.3$; FAB-MS m/z 510.2 (M+); HRMS calcd for $\mathrm{C}_{35} \mathrm{H}_{26} \mathrm{O}_{2} \mathrm{~S} 510.1653$, found 510.1657 .

Ethyl Tribenzo[fg,ij,rst]pentapheno[15,16-b]thiophene2-carboxylate (15a). To a solution of tetraphenylbenzothiophene $14 a$ (228 mg, $0.45 \mathrm{mmol})$ in $\mathrm{CH}_{2} \mathrm{Cl}_{2}(10 \mathrm{~mL})$ was added slowly a solution of $\mathrm{FeCl}_{3}\left(320 \mathrm{mg}, 3 \mathrm{mmol}\right.$ ) in $\mathrm{CH}_{3} \mathrm{NO}_{2}$ $(5 \mathrm{~mL})$. The mixture was stirred at room temperature for $5 \mathrm{~h}$, water $(10 \mathrm{~mL})$ was added, and and the mixture was extracted with $\mathrm{CH}_{2} \mathrm{Cl}_{2}$. The organic phase was dried $\left(\mathrm{Na}_{2} \mathrm{SO}_{4}\right)$, concentrated, and recrystallized from $\mathrm{CH}_{2} \mathrm{Cl}_{2}$ /hexane to give polycydic aromatic compound 15 a (183 mg, 81\%). Alternatively, treatment of 14a with excess amounts of $\mathrm{AlCl}_{3}$ and anhydrous $\mathrm{CuCl}_{2}$ in $\mathrm{CS}_{2}$ solution under the atmosphere of oxygen for 36 $\mathrm{h}$ afforded 15a in $91 \%$ yield: solid; $\mathrm{mp}>300^{\circ} \mathrm{C}$; I R (KBr) 1715 $\mathrm{cm}^{-1}$; UV $\left(\mathrm{CHCl}_{3}\right) \lambda_{\max }(\epsilon) 312 \mathrm{~nm}$ (19000), $325 \mathrm{~nm}(20300)$, $341 \mathrm{~nm}$ (21300), $380 \mathrm{~nm}$ (7700), $401 \mathrm{~nm}$ (9100), $412 \mathrm{~nm}$ (6900), $436 \mathrm{~nm}$ (5000); $\mathrm{FL}\left(\mathrm{CHCl}_{3}, \mathrm{C}=1 \times 10^{-5} \mathrm{M}\right) \lambda_{\mathrm{em}} 436$ and 472 $\mathrm{nm}$ by excitation at $436 \mathrm{~nm} ;{ }^{1} \mathrm{H} \mathrm{NMR}\left(\mathrm{CDCl}_{3}, 200 \mathrm{MHz}\right) \delta 9.25$ $(1 \mathrm{H}, \mathrm{dd}, \mathrm{J}=8.0,2.3 \mathrm{~Hz}), 9.06(1 \mathrm{H}, \mathrm{s}), 8.74-8.59(7 \mathrm{H}, \mathrm{m})$, 7.85-7.76 (6 H, m), $4.48(2 \mathrm{H}, \mathrm{q}, \mathrm{J}=7.2 \mathrm{~Hz}), 1.47(3 \mathrm{H}, \mathrm{t}, \mathrm{J}=$ $7.2 \mathrm{~Hz}) ; \mathrm{FAB}-\mathrm{MS} \mathrm{m} / \mathrm{z} 504.1\left(\mathrm{M}^{+}\right)$; HRMS calcd for $\mathrm{C}_{35} \mathrm{H}_{20} \mathrm{O}_{2} \mathrm{~S}$ 504.1184, found 504.1180. Anal. Calcd for $\mathrm{C}_{35} \mathrm{H}_{20} \mathrm{O}_{2} \mathrm{~S}$ : C, 83.31; $\mathrm{H}$, 4.00. Found: C, 83.18; $\mathrm{H}, 4.24$.

Acknowledgment. We thank the National Science Council for financial support and Mr. Gene-Hsiang Lee and Yi-Hung Liu for X-ray analyses.

Supporting Information Available: Physical and spectral data, NMR spectra, and X-ray analyses of new compounds. This material is available free of charge via the Internet at http://pubs.acs.org.

J 00257849 